\title{
REGENERATION OF OAT ANDROGENIC PLANTS IN RELATION TO INDUCTION MEDIA AND CULTURE CONDITIONS OF EMBRYO-LIKE STRUCTURES
}

\author{
AlEKSANDRA PONITKA, AURELIA ŚLUSARKIEWICZ-JARZINA \\ Institute of Plant Genetics, Polish Academy of Sciences \\ Strzeszyńska 34, 60-479 Poznań, Poland \\ e-mail: apon@igr.poznan.pl
}

(Received: October 9, 2008. Accepted: July 13, 2009)

\begin{abstract}
The effect of C17 and W14 induction media on the formation of embryo-like structures (ELS) from $\mathrm{F}_{3}$ generation of nine hexaploid oat hybrids was investigated in the study. In all genotypes, the highest number of ELS (0.6 - 12.1/100 anthers) was obtained on C17 medium. The efficiency of plant regeneration on medium 190-2 was tested, in relation to different ELS culture conditions. The highest rate of green plants per 100 ELS (3.3 - 42.4) was produced by incubation at $22^{\circ} \mathrm{C}$ in the dark for the first two weeks. Among 36 green regenerants, $28(77.8 \%)$ were haploid and $8(22.2 \%)$ were spontaneous doubled haploids, fully fertile. After colchicine treatment of haploid plants, 19 were partially fertile and set from 1 to 15 seed per panicle.
\end{abstract}

KEY WORDS: anther culture, Avena sativa, culture conditions, doubled haploids, embryo-like structures, haploid plants.

\section{INTRODUCTION}

Anther culture is an attractive technique for the rapid production of completely homozygous lines and has several uses in plant breeding, molecular genetics and biotechnology. Oat is known as a relatively recalcitrant cereal species for anther culture and its low frequency of ELS induction limits the practical application of the method. Various factors were investigated to increase ELS production and plant regeneration, such as genotype, heat or cold pretreatment of tillers before plating of anthers, the influence of the physical state of induction medium, modification of media components by use of maltose instead of sucrose and the application of different growth regulators (Rines 1983; Kiviharju et al. 1997; Kiviharju and Puolimatka 1998; Kiviharju and Pehu 1998; Kiviharju and Tauriainen 1999; Kiviharju et al. 2000, 2005; Ślusarkiewicz-Jarzina and Ponitka 2007). However, the effect of ELS culture conditions on the production of oat green plants, has not been previously tested.

The aim of this study was to investigate the androgenic response of different oat genotypes on two induction media, as well as green plant production.

\section{MATERIAL AND METHODS}

$\mathrm{F}_{3}$ generation of nine cross combination of hexaploid oat: Lisbeth x Bendicoot, Flämingsprofi x Rajtar, Scorpion x Deresz, Aragon x Deresz, Deresz x POB7219/03, Bohun x Deresz, Krezus x Flämingsprofi, Krezus x POB10440/01 and Cwał $x$ Bohun from the DANKO Plant Breeding Station-Choryń and from the Małopolska Plant Breeding Station-Polanowice, Poland were used in the experiment. Donor plants were grown in a greenhouse. Tillers were harvested when most microspores were at the uninucleate stage and then cold treated at $4^{\circ} \mathrm{C}$ for 6-9 days in the mineral salt medium N6 (Chu et al. 1975) with $2 \mathrm{mg} / \mathrm{l}$ 2,4-D. After the cold pretreatment, spikes were surface sterilized with $5 \%$ calcium hypochlorite for $8 \mathrm{~min}$, then washed several times with sterilized distilled water. Anthers were isolated aseptically and transferred onto Petri dishes containing C17 induction medium (Wang and Chen 1983) with $90 \mathrm{~g} / \mathrm{l}$ maltose (instead of sucrose) and W14 salts and vitamins (Ouyang et al. 1989) with $5.0 \mathrm{mg} / 1 \mathrm{2}, 4-\mathrm{D}+0.5 \mathrm{mg} / \mathrm{l} \mathrm{BAP}+$ $20.0 \mathrm{mg} / \mathrm{l}$ Ethephon (2-chloroethyl-phosphonic acid) + $50.0 \mathrm{mg} / \mathrm{l} \mathrm{L}$-cysteine $+500.0 \mathrm{mg} / \mathrm{l}$ myo-inositol (modified by Kiviharju et al. 2005). The media were sterilized by autoclaving at $120^{\circ} \mathrm{C}$ for $20 \mathrm{~min}$. Growth regulators were filter sterilized and added to the sterilized medium. A total of 27000 anthers were collected per $5 \mathrm{~cm} \varnothing$ Petri dish (1500 anthers of each combination, on two media). Petri dishes were sealed with parafilm and then placed into a dark incubation chamber at $28^{\circ} \mathrm{C}$. Embryo-like structures (ELS) were transferred to a regeneration medium 190-2 (Zhuang and $\mathrm{Xu} 1983$ ) and incubated at $22^{\circ} \mathrm{C}$ with a $12 \mathrm{~h}$ day photoperiod (incubation in light), while a half of the Petri dishes were incubated in the dark for the first two weeks (incuba- 
TABLE 1. Composition of C17 and W14 embryo-like structures induction media and 190-2 plant regeneration medium.

\begin{tabular}{|c|c|c|c|}
\hline Component (mg/l) & $\mathrm{C} 17$ & W14 & $190-2$ \\
\hline $\mathrm{KNO}_{3}$ & 1400 & 2000 & 1000 \\
\hline $\mathrm{NH}_{4} \mathrm{H}_{2} \mathrm{PO}_{4}$ & - & 380 & - \\
\hline$\left(\mathrm{NH}_{4}\right)_{2} \mathrm{SO}_{4}$ & - & - & 200 \\
\hline $\mathrm{NH}_{4} \mathrm{NO}_{3}$ & 300 & - & - \\
\hline $\mathrm{KH}_{2} \mathrm{PO}_{4}$ & 400 & - & 300 \\
\hline $\mathrm{CaCl}_{2} \times 2 \mathrm{H}_{2} \mathrm{O}$ & 150 & 140 & - \\
\hline $\mathrm{Ca}\left(\mathrm{NO}_{3}\right)_{2} \times 4 \mathrm{H}_{2} \mathrm{O}$ & - & - & 100 \\
\hline $\mathrm{MgSO}_{4} \times 7 \mathrm{H}_{2} \mathrm{O}$ & 150 & 200 & 200 \\
\hline $\mathrm{KCl}$ & - & - & 40 \\
\hline $\mathrm{K}_{2} \mathrm{SO}_{4}$ & - & 700 & - \\
\hline $\mathrm{KJ}$ & 0.86 & 0.5 & 0.5 \\
\hline $\mathrm{MnSO}_{4} \times 4 \mathrm{H}_{2} \mathrm{O}$ & 11.2 & 8.0 & 8 \\
\hline $\mathrm{Na}_{2} \mathrm{MoO}_{4} \times 2 \mathrm{H}_{2} \mathrm{O}$ & - & 0.005 & - \\
\hline $\mathrm{CoCl}_{2} \times 6 \mathrm{H}_{2} \mathrm{O}$ & 0.025 & 0.025 & - \\
\hline $\mathrm{H}_{3} \mathrm{BO}_{3}$ & 6.2 & 3 & 3 \\
\hline $\mathrm{ZnSO}_{4} \times 7 \mathrm{H}_{2} \mathrm{O}$ & 8.6 & 3 & 3 \\
\hline $\mathrm{CuSO}_{4} \times 5 \mathrm{H}_{2} \mathrm{O}$ & 0.025 & 0.025 & - \\
\hline $\mathrm{FeSO}_{4} \times 7 \mathrm{H}_{2} \mathrm{O}$ & 27.8 & 27.8 & 27.8 \\
\hline $\mathrm{Na}_{2}$ EDTA $\times 2 \mathrm{H}_{2} \mathrm{O}$ & 37.8 & 37.8 & 37.8 \\
\hline Pyridoxine $\mathrm{x} \mathrm{HCl}$ & 0.5 & 0.5 & 0.5 \\
\hline Nicotinic Acid & 0.5 & 0.5 & 0.5 \\
\hline Thiamine $\mathrm{x} \mathrm{HCl}$ & 1 & 2 & 1 \\
\hline Myo-Inositol & 100 & 500 & 100 \\
\hline Glycine & 2 & 2 & 2 \\
\hline L-cysteine & - & 50 & - \\
\hline Biotine & 1 & - & - \\
\hline Folic Acid & 0.5 & - & - \\
\hline NAA & - & - & 0.5 \\
\hline $2,4-\mathrm{D}$ & 1.5 & 5 & - \\
\hline Kinetin & 0.5 & - & 0.5 \\
\hline PFA & 20 & - & - \\
\hline BAP & - & 0.5 & - \\
\hline Etephon & - & 20 & - \\
\hline Sucrose $(\mathrm{g} / \mathrm{l})$ & - & - & 30 \\
\hline Maltose (g/l) & 90 & 90 & - \\
\hline Agar (g/l) & - & - & 6 \\
\hline Agarose (g/l) & 6 & 6 & - \\
\hline $\mathrm{pH}$ & 5.8 & 5.8 & 6.0 \\
\hline
\end{tabular}

tion in darkness). Table 1 shows the composition of media for anther cultures.
Green plant yield was the number of green plants obtained from 100 ELS or 100 plated anthers. Plants were potted and placed in a greenhouse. The ploidy level of green plants was determined by flow cytometry of the DNA content of the DAPI - stained nuclei from leaves (Laat de et al. 1987). For ploidy evaluation a ratio between the average channels of the tissue analysed and that of the $2 \mathrm{C}$ peak of the standard was determined. Doubled haploid plants were vernalized immediately, whereas haploid plants were treated with $0.1 \%$ colchicine solution with $4 \%$ DMSO and 25 $\mathrm{mg} / \mathrm{l} \mathrm{GA} 3$ for 6 hours in the light at $25^{\circ} \mathrm{C}$. After colchicine treatment all plants were washed in running tap water for 2 $\mathrm{h}$ and then potted in greenhouse, where they grown to maturity. The success of chromosome doubling was estimated on the basis of fertility of regenerated plants. Fertility percentage was determined by dividing the number of fertile or partially fertile panicles by the total number of tillers for each plant.

\section{RESULTS}

In this study the first ELS were observed between the sixth and eighth week of anther culture. Eight out of nine hexaploid oat cross combinations examined were capable of ELS formation on C17 medium however, only six responded on W14 medium. The frequencies of ELS were markedly influenced by genotype. A total number of 546 ELS (average 2.0/100 anthers) were obtained from both induction media. For all genotypes the induction efficiency was higher on medium $\mathrm{C} 17$, which produced 409 ELS (0.6 12.1/100 anthers), as compared to medium W14 with 137 ELS (0.6 - 3.3/100 anthers). Combination Bohun x Deresz gave the best ELS induction rates on both media (Table 2).

Table 3 presents the effect of culture conditions and genotype on plant regeneration. The frequency of green plants was influenced by light conditions during the first two weeks of ELS culture on the regeneration medium. Green plant regeneration efficiency was higher during incubation in darkness, in which 27 plants were obtained (3.3 - 42.4/100 ELS, depending on genotype), in comparison to incubation in light, where only nine plants were regenerated $(3.6$ - 16.7/100 ELS) - Fig. 1a.

Out of 27000 anthers plated from nine cross combinations during this experiment, 36 plants $(6.6 / 100$ ELS, or

TABLE 2. Frequencies of ELS formation on two induction media and plants regeneration in anther culture of oat.

\begin{tabular}{|c|c|c|c|c|c|}
\hline \multirow{2}{*}{ Cross combination } & \multicolumn{3}{|c|}{$\begin{array}{c}\text { ELS } \\
\text { No. (/100 anthers) }\end{array}$} & \multicolumn{2}{|c|}{$\begin{array}{c}\text { Plants } \\
\text { No. (/100 anthers) }\end{array}$} \\
\hline & $\begin{array}{l}\text { Medium } \\
\text { W14 }\end{array}$ & $\begin{array}{l}\text { Medium } \\
\text { C17 }\end{array}$ & Total & Green & Albino \\
\hline Aragon x Deresz & $22(1.5)$ & $41(2.7)$ & $63(2.1)$ & $1(0.03)$ & 0 \\
\hline Scorpion x Deresz & 0 & $27(1.8)$ & $27(0.9)$ & 0 & $3(0.1)$ \\
\hline Flämingsprofi x Rajtar & $14(0.9)$ & $49(3.3)$ & $63(2.1)$ & $19(0.6)$ & $5(0.2)$ \\
\hline Deresz x POB7219/03 & 0 & $9(0.6)$ & $9(0.3)$ & 0 & 0 \\
\hline Bohun x Deresz & $49(3.3)$ & $182(12.1)$ & $231(7.7)$ & $14(0.5)$ & $2(0.1)$ \\
\hline Krezus x Flämingsprofi & 0 & 0 & 0 & 0 & 0 \\
\hline Krezus x POB10440/01 & $10(0.7)$ & $29(1.9)$ & $39(1.3)$ & 0 & $1(0.03)$ \\
\hline Cwał x Bohun & $33(2.2)$ & $33(2.2)$ & $66(2.2)$ & 0 & $1(0.03)$ \\
\hline Total & $137(1.0)$ & $409(3.0)$ & $546(2.0)$ & $36(0.1)$ & $12(0.04)$ \\
\hline
\end{tabular}


TABLE 3. Efficiency of oat green plants regeneration from embryo-like structures cultured under different conditions.

\begin{tabular}{|c|c|c|c|c|c|}
\hline \multirow{2}{*}{ Cross combination } & \multicolumn{2}{|c|}{ Incubation in light } & \multicolumn{2}{|c|}{ Incubation in darkness } & \multirow{2}{*}{$\begin{array}{c}\text { Total green plants } \\
\text { No. (/100 ELS) }\end{array}$} \\
\hline & $\begin{array}{l}\text { ELS } \\
\text { No. }\end{array}$ & $\begin{array}{c}\text { Plants } \\
\text { No. (/100 ELS) }\end{array}$ & $\begin{array}{l}\text { ELS } \\
\text { No. }\end{array}$ & $\begin{array}{c}\text { Plants } \\
\text { No. }(/ 100 \text { ELS })\end{array}$ & \\
\hline Aragon x Deresz & 33 & 0 & 30 & $1(3.3)$ & $1(1.6)$ \\
\hline Scorpion x Deresz & 13 & 0 & 14 & 0 & 0 \\
\hline Flämingsprofi x Rajtar & 30 & $5(16.7)$ & 33 & $14(42.4)$ & $19(30.2)$ \\
\hline Deresz x POB7219/03 & 9 & 0 & 0 & 0 & 0 \\
\hline Bohun x Deresz & 110 & $4(3.6)$ & 121 & $10(8.3)$ & $14(6.1)$ \\
\hline Krezus x POB10440/01 & 20 & 0 & 19 & 0 & 0 \\
\hline Cwał x Bohun & 33 & 0 & 33 & 0 & 0 \\
\hline Total & 272 & $9(3.3)$ & 274 & $27(9.8)$ & $36(6.6)$ \\
\hline
\end{tabular}

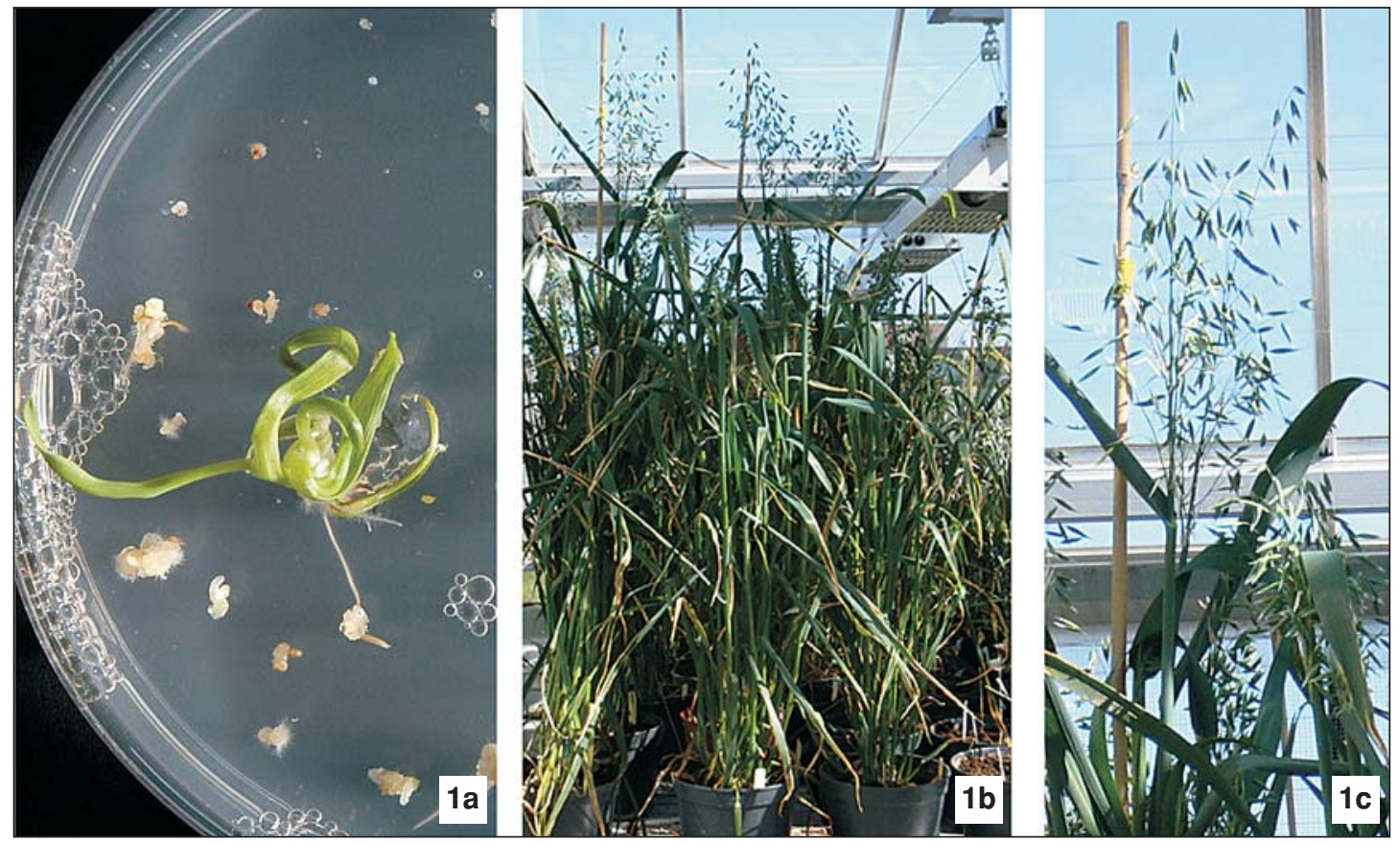

Fig. 1a. Plantlet developed from ELS on regeneration medium after four weeks from cross combination Lisbeth $\mathrm{x}$ Bendicoot. Figs $1 \mathrm{~b}$ and $1 \mathrm{c}$. Oat regenerants in the greenhouse and panicles of fertile plants from Flämingsprofi x Rajtar.

$0.1 / 100$ anthers) were produced on both induction media under incubation in darkness and light. ELS obtained from only four cross combinations produced green rooted plants: one plant of Aragon x Deresz (0.03/100 anthers or 1.6/100 ELS), two plants of Lisbeth $x$ Bendicoot $(0.07 / 100$ anthers or 4.2/100 ELS), 19 plants of Flämingsprofi x Rajtar $(0.6 / 100$ anthers or 30.2/100 ELS) and 14 plants of Bohun $x$ Deresz $(0.5 / 100$ anthers or $6.1 / 100$ ELS). It should be stressed that a relatively high number of ELS did not always result in a high number of green plants, for example for Aragon x Deresz only 1.6 plants per 100 ELS were formed. Despite a low ELS induction rate of Flämingsprofi x Rajtar, it produced the highest number of regenerants (30.2/100 ELS). The ploidy levels of plants, as determined by flow cytometry, showed that among the 36 green regenerants, $28(77.8 \%)$ were haploid and eight $(22.2 \%)$ spontaneously doubled haploids. As all plants were regenerated from ELS originating inside pollen sacks of anthers, it is assumed that diploids were spontaneous doubled haploids and not regenerants from diploid tissues of the anther itself. Among obtained plants spontaneous chromosome doubling was observed for two cross combinations: five plants $(26.3 \%)$ of Flämingsprofi x Rajtar and three plants $(21.4 \%)$ of Bohun x Deresz. All eight diploids were fully fertile. Out of 28 haploid plants, after colchicine treatment nine were sterile and formed panicles, but set no seeds, and 19 plants set 1 to 15 seeds per panicle. The number of panicles developing seeds varied from 5.9 to $69.2 \%$ in several plants. The overall efficiency of doubled haploids production was 27 lines, among which eight were spontaneously doubled haploids and 19 after colchicine treatment (Figs 1b, 1c and 2).

\section{DISCUSSION}

This study and other publications clearly demonstrated the importance of the induction medium for ELS formation. In our study the effect of selected media, i.e. W14 and C17 was investigated. It was shown that ELS induction rate was generally increased by the use of medium $\mathrm{C} 17$ with maltose, instead of sucrose, as compared to medium W14. 


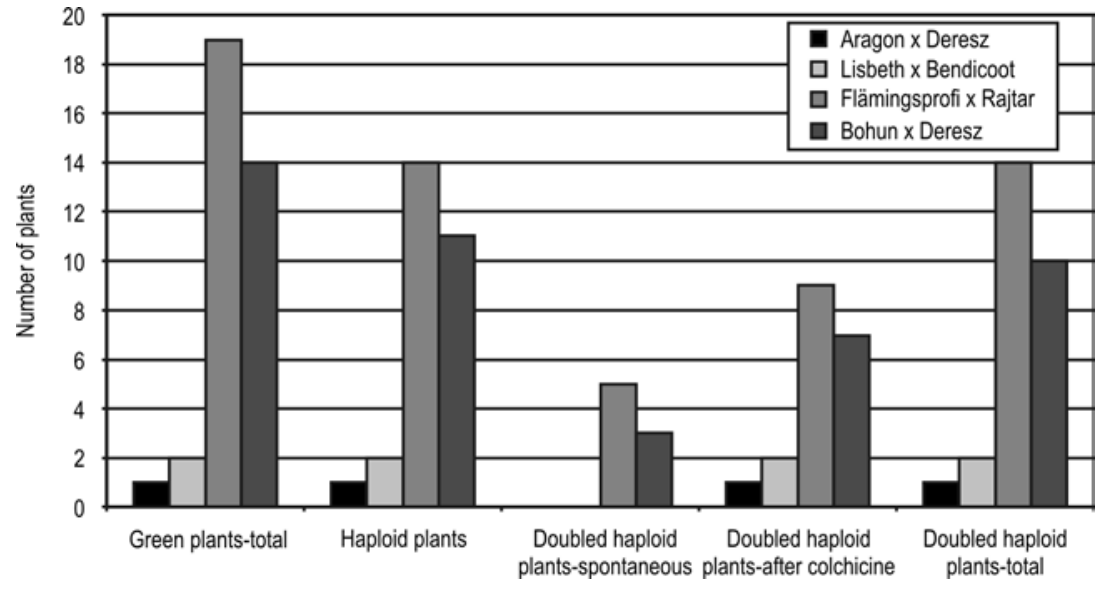

Fig. 2. Frequencies of oat green plants, haploid and doubled haploid (spontaneous and after colchicine tratment) obtained from anther culture.
The latter, previously used for Polish oat cultivars (Ślusarkiewicz-Jarzina and Ponitka 2007), did not yield results similar to those described by Kiviharju et al. (2005). Therefore, to improve the efficiency of ELS production, the C17 medium is proposed, resulting in a very high frequency of ELS induction also in triticale (Ponitka et al. 1999; Ponitka and Ślusarkiewicz-Jarzina 2007), wheat (Otani and Shimada 1995; Saidi et al. 1997), rye (Bicar and Darvey 1997) and amphiploid Aegiops variabilis x Secale cereale (Ponitka and Ślusarkiewicz-Jarzina 2002).

The effect of light conditions on plant regeneration during the first two weeks of ELS culture is also presented in this paper. The frequency of green plants was higher when the first two weeks of ELS incubation on the regeneration medium took place in the darkness. Up to now, there were a few papers studying the influence of light on green plant production. Ziegler et al. (1990) reported that in wheat significantly more green plants were produced when light was absent during the differentiation process, than under low light conditions. Ponitka et al. (1999) showed that the triticale plant regeneration was influenced by temperature and light conditions during the first week culture of ELS. The results of our study suggest that the number of ELS and regenerated green plants in oat can be increased by using induction medium $\mathrm{C} 17$ and applying appropriate physical conditions $\left(22^{\circ} \mathrm{C}\right.$ in the dark) during the first two weeks of ELS culture on the regeneration medium.

The parental components were observed to have a important influence on green plant regeneration. For example the highest percent of plants was obtained when cv. Flämingsprofi was used as a female component, whereas no androgenesis response was observed when this cultivar was used as a male component. In contrast, using cv. Deresz as a male parent (Aragon x Deresz and Bohun x Deresz) resulted in obtaining green plants, however in that cross combination, in which cv. Deresz was treated as a female parent no plant was produced.

Most plants (77.8\%) were haploid, $32.1 \%$ of which were sterile and did not set seed after colchicines treatment. Among doubled haploid plants the number of panicles developing seeds varied from 5.9 to $69.2 \%$ in particular plants. In contrast, Kiviharju et al. (2000) reported, that all regenerants treated with colchicine produced seeds, with the percentage of fertile panicles ranging from 10 to $100 \%$. However, in our experiments $22.2 \%$ of plants were spontaneously doubled haploids, fully fertile. A phenomenon of spontaneous doubling was also observed in oat anther culture by Kiviharju et al. (1997, 2000) who obtained 15.4 and $33.3 \%$ doubled haploids. Ślusarkiewicz-Jarzina and Ponitka (2003) reported that the frequency of spontaneously doubled haploids of triticale, derived from anther culture, was genotype-dependent and was quite high (average $57.5 \%$ for seven genotypes).

In conclusion, only Kiviharju et al. (2005) reported significantly high plant regeneration rates (30 green plants per 100 anthers) and a total number of over 500 regenerants from two oat cultivars. These results are close to the rate of DH- production acceptable for breeding and genetic study purposes. Since our results for Polish oat cultivars were not fully satisfying, further experiments on androgenic response improvement are needed.

\section{LITERATURE CITED}

BICAR E.H., DARVEY N.L. 1997. Development of the components of a cytoplasmic male sterility hybrid system in rye through anther culture. Euphytica 97: 151-160.

CHU C.C., WANG C., SUN C.S., HSU C., YIN K.C., CHU C.Y., BI F.Y. 1975. Establishment of an efficient medium for anther culture of rice through comparative experiments on the nitrogen sources. Sci. Sin. 18: 659-668.

KIVIHARJU K., PUOLIMATKA M., PEHU E. 1997. Regeneration of anther-derived plants of Avena sterilis. Plant Cell Tiss. Org. Cult. 48: 147-152.

KIVIHARJU E., PEHU E. 1998. The effect of cold and heat pretreatments on anther culture response of Avena sativa and $A$. sterilis. Plant Cell Tiss. Org. Cult. 54: 97-104.

KIVIHARJU E., PUOLIMATKA M. 1998. The effect of genotype on anther culture response of cultivated and wild oats. Agricult. and Food Sci. in Finland. 7: 409-422.

KIVIHARJU E.M., TAURIAINEN A.A. 1999. 2,4-Dichlorophenoxyacetic acid and kinetin in anther culture of cultivated and wild oats and their interspecific crosses: plant regeneration from A. sativa L. Plant Cell Rep. 18: 582-588.

KIVIHARJU E., PUOLIMATKA M., SAASTAMOINEN M. 2000. Extension of anther culture to several genotypes of cultivated oats. Plant Cell Rep. 19: 674-679.

KIVIHARJU E., MOISANDER S., LAURILA J. 2005. Improved green plant regeneration rates from oat anther culture and the agronomic performance of some DH lines. Plant Cell Tiss. Org. Cult. 81: 1-9.

LAAT de A.M.M., GÖHDE W., VOGELZANG M.J.D.C. 1987. Determination of ploidy of single plants and plant populations by flow cytometry. Plant Breed. 99: 303-307. 
OTANI M., SHIMADA T. 1995. Effect of synthetic medium on microspore-derived embryoid formation of tetraploid wheat. Cereal Res. Comm. 23: 345-350.

OUYANG J.W., JIA S.E., ZHANG C., CHEN X.D., FENG G.H. 1989. A new synthetic medium ( $\mathrm{W}_{14}$ medium) for wheat anther culture. Annual Report, Institute of Genetics, Academia Sinica (1986-1988): 91-92.

PONITKA A., ŚLUSARKIEWICZ-JARZINA A., WĘDZONY M., MARCIŃSKA I., WOŹNA J. 1999. The influence of various in vitro culture conditions on androgenetic embryo induction and plant regeneration from hexaploid triticale (x Triticosecale Wittm.). J. Appl. Genet. 40: 165-174.

PONITKA A., ŚLUSARKIEWICZ-JARZINA A. 2002. Production of haploids and doubled haploids of the amphiploids $A e$ gilops variabilis x Secale cereale. Cereal Res. Comm. 30: 1-2.

PONITKA A., ŚLUSARKIEWICZ-JARZINA A. 2007. The effect of liquid and solid medium on production of winter triticale (x Triticisecale Wittm.) anther-derived embryos and plants. Cereal Res. Comm. 35: 15-22.

RINES H.W. 1983. Oat anther culture: Genotype effect on callus initiation and the production of a haploid plant. Crop Sci. 23: 268-272.
SAIDI N., CHERKAOUI S., CHLYAH A., CHLYAH H. 1997. Embryo formation and regeneration in Triticum turgidum ssp. durum anther culture. Plant Cell Tiss. Org. Cult. 51: 27-33.

ŚLUSARKIEWICZ-JARZINA A., PONITKA A. 2003. Efficient production of spontaneous and induced doubled haploid triticale plants derived from anther culture. Cereal Res. Comm. 31: 289-296.

ŚLUSARKIEWICZ-JARZINA A., PONITKA A. 2007. The effect of physical medium state on anther culture response in Polish cultivated oat (Avena sativa L.). Acta Biol. Cracov. Ser. Bot. 49: 27-31.

WANG P., CHEN Y. 1983. Preliminary study on production of height of pollen $\mathrm{H} 2$ generation in winter wheat grown in the field. Acta Agron. Sin. 9: 283-284.

ZHUANG J.J., XU J. 1983. Increasing differentiation frequencies in wheat pollen callus. In: Cell and Tissue Culture Techniques for Cereal Crop Improvement, Science Press. Beijing: 431.

ZIEGLER G., DRESSLER K., HESS D. 1990. Investigations on the anther culture ability of four German spring wheat cultivars and the influence of light on regeneration of green vs. albino plants. Plant Breed. 105: 40-46. 